\begin{abstract}
HHS Public Access
Author manuscript

Methods Mol Biol. Author manuscript; available in PMC 2018 July 12.

Published in final edited form as:

Methods Mol Biol. 2013 ; 948: 251-262. doi:10.1007/978-1-62703-140-0_17.

\section{Lipopeptide Delivery of siRNA to the Central Nervous System}

\author{
Mark D. Zabel
}

\section{Abstract}

RNA interference is a relatively new tool used to silence specific genes in diverse biological systems. The development of this promising new technique for research and therapeutic use in studying and treating neurological diseases has been hampered by the lack of an efficient way to deliver siRNA transvascularly across the blood-brain barrier (BBB) to the central nervous system (CNS). Here we describe a method for delivering siRNA to the CNS by complexing it to a peptide that acts as a neuronal address by binding to acetylcholine receptors (AchRs). Adding cationic liposomes to the complex protects it from serum nucleases and proteases en route. When injected intravenously, these liposome-siRNA-peptide complexes resist serum degradation, effectively cross the BBB, and deliver siRNA to AchR-expressing cells to suppress protein expression in the CNS.
\end{abstract}

\title{
Keywords
}

RNAi; siRNA; Delivery; Central nervous system; Blood-brain barrier; Liposomes; Peptides; Complexes; Prions

\section{Introduction}

Ribonucleic acid interference (RNAi) is a relatively new discovery in cell biology that diverse organisms use to help regulate the amount of messenger RNA (mRNA) available for translation. Dicer, an endogenous mammalian protein complex that mediates RNAi, cleaves double-stranded or short hairpin RNA (shRNA) into functional, small interfering RNA (siRNA). The RNA-induced silencing complex (RISC) guides siRNA to its complementary mRNA target, which is then digested by argonaut, an endonuclease present in the RISC. A concomitant reduction in protein expression ensues. Researchers have begun exploiting RNAi as a tool for silencing specific genes in biological systems (1-4). RNAi has shown

\footnotetext{
${ }^{16}$ LSPCs can be monitored in live mice by injecting them with fluorochrome-labeled LSPCs, which can be visualized using a Xenogen (Ivis) or a similar live animal imager. We observed LSPC delivery in as little as 2 min using this technique (Fig. 2) and detected LSPCs up to 10 days after injection (11).

${ }^{17}$ LSPC localization can be observed in the CNS by fluorescent microscopy (11). Euthanize injected mice and remove and snapfreeze their brains in OCT (Tissue Tek) in liquid nitrogen. Using a cryostat cooled to $-20^{\circ} \mathrm{C}$ (Leica), cut 8- $\mu \mathrm{m}$-thick brain sections and mount them on glass slides. Fix in ice-cold acetone for $10 \mathrm{~min}$ and air-dry overnight. Slides can be stained with additional markers (the protein knockdown target, for example) or DAPI before mounting in ProLong Gold (Invitrogen) or a similar anti-fade mounting media. Visualize LSPCs in brain sections using a microscope capable of detecting the fluorochromes used (Fig. 3a-t).

${ }^{18}$ Quantitative analysis of LSPC delivery can be performed on brain cells isolated from injected mice by flow cytometry (11). Sacrifice mice and remove their brains. Strain an approximately 1-mm-thick brain section through a $45 \mu \mathrm{m}$ nylon mesh (Fisher Scientific) to produce a single cell suspension. Cells can be stained with additional cell marker of interest (the protein knockdown target) and analyzed using a Cyan (BD Pharmingen) or a similar flow cytometer (Fig. 3u-w).
} 
potential efficacy in treating several diseases including hepatitis $(5,6)$, cancer $(7)$, ocular disorders (8), chronic pain (9), and neuropathologies induced by viruses (10) and prions (11). Initial attempts to use RNAi in the central nervous system (CNS) primarily used intracranial (ic) injections of lentiviral vectors encoding shRNA. Lentivirus encoding shRNA against mRNA transcripts has demonstrated decreased expression of the cognate protein $(12,13)$, but several aspects of this method limit its efficacy. Inadequate neuroinvasion by lentiviral vectors across the blood-brain barrier (BBB) necessitates their direct delivery to the CNS via stereotactic intracranial injection of shRNA lentivirus directly into the brain. Even then, lentiviral infection and shRNA expression were limited to a small area around the injection site, resulting in spatially limited knockdown of protein expression. This method also lacks desired temporal control of protein expression, since once brain cells are infected with lentivirus, it will likely irreversibly suppress protein expression in these cells. Moreover, despite improvements in lentiviral vector technology and construction (1417), concerns over the oncogenic capacity of lentiviral delivery systems remain (18-20).

Nonviral strategies to deliver siRNA molecules to cells include using cationic peptides capable of crossing plasma membranes (21-23). Conjugating siRNA to these cellpenetrating peptides via thiol linkages allows for efficient dissociation of siRNA-peptide complexes by reduction of the disulfide bond in the cytoplasm $(24,25)$. While this delivery method holds therapeutic promise, it still does not solve two important problems of drug delivery to the brain: cell specificity and transport of its cargo across the BBB. Kumar et al. developed a transvascular method to deliver siRNA across the BBB specifically to neuronal cells in the brain via intravenous (iv) injection (10). This method involves complexing siRNA to a short peptide derived from the rabies virus glycoprotein that binds specifically to acetylcholine receptors (AchRs) on neuronal cells (26, 27). Adding nine D-Arginines to the carboxyl terminus of this peptide (RVG-9r) enabled it to electrostatically interact with siRNA and specifically deliver siRNA to neurons in mouse brains to suppress protein expression and protect against fatal viral encephalitis. This significant advance in siRNA delivery to the CNS was tempered by the lack of direct detection of siRNA in the brains of a majority of treated mice, suggesting that these naked complexes may have degraded significantly in the blood during transport. Efficient peptide-mediated delivery of siRNA to the brain after iv injection relies on protecting the complex from serum nuclease and protease degradation en route.

Complexing or encapsulating siRNA with liposomes has been shown to protect siRNA from degradation and improve delivery through the vasculature (28-33). Adding polyethylene glycol (PEG) to lipids increases bioavailability and circulation time in blood (34-36) by decreasing immune clearance (37). PEGylated liposomes increased delivery of doxorubicin and cisplatin in experimental tumor models $(38,39)$ and have been used in clinical trials to treat a variety of cancers (40), including AIDS-related Kaposi's sarcoma $(41,42)$ and advanced malignant solid tumors (43), including those found in ovarian (44) and breast (45) cancer.

While protecting therapeutic agents from serum degradation represents a crucial step in transvascular delivery to target sites in the brain, liposomes alone do not provide cellspecific delivery, nor do they ensure transport across the BBB. Coupling a monoclonal 
antibody against glial fibrillary acidic protein (GFAP) to PEGylated liposomes successfully targeted them to astrocytes in cell culture, but still failed to deliver them across the BBB to astrocytes in mouse brains (46). An effective, efficient delivery system must do all three: (1) provide a molecular address to the agent for delivery to neuronal cells, (2) gain access to the brain by crossing the $\mathrm{BBB}$, and (3) protect the agent from serum degradation en route. Using siRNA as a therapeutic agent and prion diseases as models, we have developed a therapeutic delivery system that addresses all of these issues. By complexing siRNA targeting mRNA transcripts encoding $\mathrm{PrP}^{\mathrm{C}}$ to cationic liposomes, and then adding the RVG-9r peptide, we have created liposome-siRNA-peptide complexes (LSPCs) that effectively cross the BBB and deliver PrP siRNA to AchR-expressing cells to suppress $\operatorname{PrP}^{\mathrm{C}}$ expression in vivo.

\section{Materials}

\subsection{LSPC Reagents}

1. siRNA: Designed using siRNA scales (47) and synthesized, pre-annealed, and lyophilized by Qiagen (see Note 1 ). Resuspend in sterile RNAse-free water (supplied by Qiagen) to $20 \mu \mathrm{M}$ according to the manufacturer's directions. Store in single-use aliquots at $-70^{\circ} \mathrm{C}$ (see Note 2).

2. Peptides: RVG-9r and control RVM-9r peptides (Table 1) were synthesized and purified by high-performance liquid chromatography by Global Peptide (www.globalpeptide.com). Resuspend in sterile phosphate-buffered saline (PBS), $\mathrm{pH} 7.4$ to $400 \mu \mathrm{M}$, or approximately $2 \mathrm{mg} / \mathrm{mL}$. For example, resuspend $100 \mathrm{mg}$ of peptide in $50 \mathrm{~mL}$ PBS. Store at $-70^{\circ} \mathrm{C}$ in single-use aliquots (typically 400 $\mu \mathrm{L}$, see Note 2).

3. $10 \%$ Sterile sucrose: Weigh $1 \mathrm{~g}$ of sucrose and mix into $9 \mathrm{~mL}$ of sterile deionized water.

4. $\quad$ Liposomes: Prepare cationic liposomes by mixing $N$-[1-(2,3Dioleoyloxy)propyl]- $N, N, N$-trimethylammonium chloride (DOTAP, SigmaAldrich, St. Louis, MO) and cholesterol (NOF America, Irvine, CA) in chloroform at 1:1 molar ratio to a final concentration of $2 \mathrm{mM}$. Weigh and mix $14 \mathrm{mg}$ of DOTAP and $7.7 \mathrm{mg}$ of cholesterol into $10 \mathrm{~mL}$ of chloroform (see Note 3 ) in a round-bottom, $15-\mathrm{mL}$ glass tube. Place the tube in a vacuum desiccator and dry overnight to a thin film (see Note 4 ).

Rehydrate lipids to a final concentration of $10 \mathrm{mM}$ in sterile $10 \%$ sucrose. Add $2 \mathrm{~mL}$ of sucrose solution to the glass tube containing the lyophilized lipids and mix by pipetting.

\footnotetext{
${ }^{1}$ We have used siRNA prepared for us by several biotechnology companies, but have observed optimal knockdown using siRNA prepared from Qiagen. Additionally, Qiagen can label siRNA with Alexa fluorochromes to monitor LSPC trafficking for determining delivery kinetics (see Note 15).

${ }^{2}$ We typically treat cages of five mice at a time and therefore aliquot $1 \mathrm{~mL}$ of $200 \mu \mathrm{M}$ stock siRNA, enough to treat five mice. Aliquots should be adjusted to meet researchers' experimental requirements.

${ }^{3}$ Accurately weighing these amounts requires a microbalance. Alternatively, prepare a $20 \mathrm{mM}$ stock by mixing $140 \mathrm{mg}$ of DOTAP and $77 \mathrm{mg}$ of cholesterol into chloroform to a final volume of $10 \mathrm{~mL}$, and then dilute $1 \mathrm{~mL}$ of this solution into $9 \mathrm{~mL}$ of chloroform to a final concentration of $2 \mathrm{mM}$. Store the $20 \mathrm{mM}$ stock at room temperature protected from air and light for up to several months.

${ }^{4}$ Desiccation time may vary. Most importantly, the lipids must be completely dry. For faster desiccation, the solution can be split into several tubes.
} 
Incubate for $1 \mathrm{~h}$ at $50^{\circ} \mathrm{C}$, and then at room temperature for $2 \mathrm{~h}$. Mix and serially filter through 1, 0.45, and $0.2 \mu \mathrm{m}$ pore filters (Pall Life Sciences). Store in sterile tubes at $4^{\circ} \mathrm{C}$ for up to several months until ready to use.

Dilute liposomes to $200 \mu \mathrm{M}$ working concentration 1:100 in sterile PBS immediately prior to use. For example, briefly mix stock liposomes by pipetting and add $2-198 \mu \mathrm{L}$ sterile PBS. Mix by pipetting and put $100 \mu \mathrm{L}$ into two $200 \mu \mathrm{L}$ thin-walled PCR tubes (VWR). Seal tubes shut with parafilm and place into the tube holder of MP4000 horn sonicator (Qsonica). Sonicate liposomes for $40 \mathrm{~s}$ at $75 \%$ maximum power (see ${ }^{\text {Note }} 5$ ). The liposomes can be used immediately for complexation, or stored for several weeks at $4^{\circ} \mathrm{C}$ (see ${ }^{\text {Note }} 6$ ).

\subsection{LSPC Delivery Supplies}

1. Mice: Choose mouse lines and strains appropriate for the experimental design. Various strains of wild-type mice can be purchased from Charles River or Jackson labs (see Note 7 ).

2. 26-30 Gauge insulin syringes.

3. Heat lamp.

4. Rodent anesthesia machine dispensing Isoflurane/Oxygen (Parkland Scientific, see Note 8 ).

\section{Methods}

\subsection{Preparing LSPCs}

Complex siRNA, liposomes, and peptides using filter barrier tips and sterile technique in a cell culture hood. The following preparation will produce enough LSPCs to treat five mice.

1. Thaw $1 \mathrm{~mL}$ of stock siRNA and $400 \mu \mathrm{L}$ stock peptides on ice.

2. Add $100 \mu \mathrm{L}$ of $200 \mu \mathrm{M}$ stock liposomes (sonicate first if necessary, see ${ }^{\text {Note }} 6$ ) to $1 \mathrm{~mL}$ of $20 \mu \mathrm{M}$ siRNA and mix gently by pipetting.

3. Incubate at room temperature for $10 \mathrm{~min}$ (Fig. 1).

4. Add $500 \mu \mathrm{L}$ of peptide, mix gently by pipetting, and incubate at room temperature for $10 \mathrm{~min}$ (see Note 9 ).

\subsection{Injecting LSPCs}

1. Warm mice in their cage by placing it $4-6$ in. below a heat lamp for $5-10 \mathrm{~min}$ (see Note 10).

\footnotetext{
${ }^{5}$ Do not sonicate more than $100 \mu \mathrm{L}$ per tube using this sonicator. Other sonicators may be used, but volumes may have to be increased significantly if a probe sonicator is used. Horn sonicators produce the best, most consistent results with the small volumes used here 6If used later, sonicate liposomes again prior to complexation.

${ }^{7}$ White mice (FVB, C3H, CD-1, for example) tend to be much easier to inject intravenously in the tail than brown or black mice (129sv, C57/B16).

${ }^{8}$ The machine should have an incubating chamber and a nose cone. We recommend isoflurane, but alternative anesthesia, such as ketamine, can be used. While tail vein injections can be done using physical restraint, we strongly recommend using chemical restraint to avoid sudden movements from the mouse that can compromise the injection and waste valuable time and reagents.

${ }^{9}$ LSPCs are ready to use in $10 \mathrm{~min}$, but are stable for several hours at room temperature.
} 
2. While warming the mice, turn on the anesthesia machine such that oxygen flows at a rate of $3-4 \mathrm{~L} / \mathrm{min}$. Turn on the isoflurane at $3 \mathrm{~L} / \mathrm{min}$.

3. When the tail vasculature is clearly visible, place a single mouse in the anesthesia chamber until its respiration visibly slows to $1-2$ breaths per second (see Note 11 ).

4. Meanwhile, load $300 \mu \mathrm{L}$ of LSPCs into a sterile insulin syringe (see ${ }^{\text {Note } 12}$ ).

5. Place the mouse on a flat surface with its face in the nose cone attached to the anesthesia machine (see Note 13 ).

6. Starting with the mouse laying on its ventral side (dorsal side up), locate one of the two lateral veins. Starting as far posterior as possible, rotate the tail slightly and insert the needle with the bevel up at a shallow $10-15^{\circ}$ angle $1-2 \mathrm{~mm}$ into the vein. Slowly press the plunger to inject the LSPC solution (see Note 14 ).

\section{References}

1. Fire A, Xu S, Montgomery MK, Kostas SA, Driver SE, Mello CC. Potent and specific genetic interference by double-stranded RNA in Caenorhabditis elegans. Nature. 1998; 391:806-811. [PubMed: 9486653]

2. McCaffrey AP, Meuse L, Pham TT, Conklin DS, Hannon GJ, Kay MA. RNA interference in adult mice. Nature. 2002; 418:38-39. [PubMed: 12097900]

3. Paddison PJ, Caudy AA, Hannon GJ. Stable suppression of gene expression by RNAi in mammalian cells. Proc Natl Acad Sci USA. 2002; 99:1443-1448. [PubMed: 11818553]

4. Paddison PJ, Hannon GJ. RNA interference: the new somatic cell genetics? Cancer Cell. 2002; 2:17-23. [PubMed: 12150821]

5. Giladi H, Ketzinel-Gilad M, Rivkin L, Felig Y, Nussbaum O, Galun E. Small interfering RNA inhibits hepatitis B virus replication in mice. Mol Ther. 2003; 8:769-776. [PubMed: 14599810]

6. McCaffrey AP, Nakai H, Pandey K, Huang Z, Salazar FH, Xu H, Wieland SF, Marion PL, Kay MA. Inhibition of hepatitis B virus in mice by RNA interference. Nat Biotechnol. 2003; 21:639-644. [PubMed: 12740585]

7. Pai SI, Lin YY, Macaes B, Meneshian A, Hung CF, Wu TC. Prospects of RNA interference therapy for cancer. Gene Ther. 2006; 13:464-477. [PubMed: 16341059]

8. Campochiaro PA. Potential applications for RNAi to probe pathogenesis and develop new treatments for ocular disorders. Gene Ther. 2006; 13:559-562. [PubMed: 16195702]

\footnotetext{
${ }^{10}$ This step is crucial for successful tail vein injections, especially in dark-colored mice. The cage should reach an ambient temperature between 32 and $35^{\circ} \mathrm{C}$. The lateral tail veins and/or the ventral artery should be clearly visible before proceeding. This usually coincides with salivation, so look for moisture around the mouth and nose. Monitor mice under the heat lamp every 2 min for signs of distress or hyperthermia. Do not leave a mouse cage under the heat lamp for more than 15 consecutive minutes.

$1 \mathrm{f}$ This should take 1-3 min. Isoflurane is very safe and accidental overdoses are very rare. Distressed mice can be given pure oxygen to help revive them if necessary.

12 If bubbles appear, hold the syringe vertically with the needle pointing up and flick the syringe until the bubbles dislodge and float to the top of the syringe, toward the needle. Carefully keeping the needle tip above the syringe barrel, place it on the inside of the tube containing the LSPCs and gently push the syringe plunger until the bubbles are evacuated (i.e., when a small amount of liquid emerges from the needle). Load additional LSPC mixture into the syringe to $300 \mu \mathrm{L}$ if necessary.

${ }_{13}$ Mice can be placed in physical restraints at this time if desired, but we recommend simultaneous chemical restraint.

${ }^{14}$ Curling the tail over a finger can help orient the tail in a position that facilitates inserting the needle at the shallow $10-15^{\circ}$ angle required for entering the vein. You should, but not always, feel the needle entering the vein lumen. You should feel little or no resistance on the plunger if you are in the lumen, and you will often see the vein blanche as the solution displaces the blood. If you feel resistance or see the tail swell just anterior to the injection site, stop immediately. You are most likely not in the vein. Apply direct pressure to the injection site for a few seconds and then attempt the injection again further anterior to the previous site. One typically has three opportunities for a successful injection per vein. If the injection is unsuccessful in both veins, turn the mouse over and try injecting into the ventral artery. If this fails, or if the vasculature is no longer visible, stop. Allow the mouse to recover, proceed to the next mouse, and try injecting the former mouse after attempting the others.
} 
9. Dorn G, Patel S, Wotherspoon G, Hemmings-Mieszczak M, Barclay J, Natt FJ, Martin P, Bevan S, Fox A, Ganju P, Wishart W, Hall J. siRNA relieves chronic neuropathic pain. Nucleic Acids Res. 2004; 32:e49. [PubMed: 15026538]

10. Kumar P, Wu H, McBride JL, Jung KE, Kim MH, Davidson BL, Lee SK, Shankar P, Manjunath N. Transvascular delivery of small interfering RNA to the central nervous system. Nature. 2007; 448:39-43. [PubMed: 17572664]

11. Pulford B, Reim N, Bell A, Veatch J, Forster G, Bender H, Meyerett C, Hafeman S, Michel B, Johnson T, Wyckoff AC, Miele G, Julius C, Kranich J, Schenkel A, Dow S, Zabel MD. LiposomesiRNA-peptide complexes cross the blood-brain barrier and significantly decrease PrP on neuronal cells and PrP in infected cell cultures. PLoS One. 2010; 5:e11085. [PubMed: 20559428]

12. Pfeifer A, Eigenbrod S, Al-Khadra S, Hofmann A, Mitteregger G, Moser M, Bertsch U, Kretzschmar H. Lentivector-mediated RNAi efficiently suppresses prion protein and prolongs survival of scrapie-infected mice. J Clin Invest. 2006; 116:3204-3210. [PubMed: 17143329]

13. White MD, Farmer M, Mirabile I, Brandner S, Collinge J, Mallucci GR. Single treatment with RNAi against prion protein rescues early neuronal dysfunction and prolongs survival in mice with prion disease. Proc Natl Acad Sci USA. 2008; 105:10238-10243. [PubMed: 18632556]

14. D'Costa J, Mansfield SG, Humeau LM. Lentiviral vectors in clinical trials: current status. Curr Opin Mol Ther. 2009; 11:554-564. [PubMed: 19806504]

15. Dissen GA, Lomniczi A, Neff TL, Hobbs TR, Kohama SG, Kroenke CD, Galimi F, Ojeda SR. In vivo manipulation of gene expression in non-human primates using lentiviral vectors as delivery vehicles. Methods. 2009; 49:70-77. [PubMed: 19559089]

16. Lundberg C, Bjorklund T, Carlsson T, Jakobsson J, Hantraye P, Deglon N, Kirik D. Applications of lentiviral vectors for biology and gene therapy of neurological disorders. Curr Gene Ther. 2008; 8:461-473. [PubMed: 19075629]

17. Nanou A, Azzouz M. Gene therapy for neurodegenerative diseases based on lentiviral vectors. Prog Brain Res. 2009; 175:187-200. [PubMed: 19660657]

18. Mulligan RC. The basic science of gene therapy. Science. 1993; 260:926-932. [PubMed: 8493530]

19. Quinonez R, Sutton RE. Lentiviral vectors for gene delivery into cells. DNA Cell Biol. 2002; 21:937-951. [PubMed: 12573051]

20. Subramanya S, Kim S-S, Manjunath N, Shankar P. RNA interference-based therapeutics for human immunodeficiency virus HIV-1 treatment: synthetic siRNA or vector-based shRNA? Expert Opin Biol Ther. 2010; 10:201-213. [PubMed: 20088715]

21. Akhtar S, Benter IF. Nonviral delivery of synthetic siRNAs in vivo. J Clin Invest. 2007; 117:36233632. [PubMed: 18060020]

22. Mathupala SP. Delivery of small-interfering RNA (siRNA) to the brain. Expert Opin Ther Pat. 2009; 19:137-140. [PubMed: 19441914]

23. Meade BR, Dowdy SF. Enhancing the cellular uptake of siRNA duplexes following noncovalent packaging with protein transduction domain peptides. Adv Drug Deliv Rev. 2008; 60:530-536. [PubMed: 18155315]

24. Chiu YL, Ali A, Chu CY, Cao H, Rana TM. Visualizing a correlation between siRNA localization, cellular uptake, and RNAi in living cells. Chem Biol. 2004; 11:1165-1175. [PubMed: 15324818]

25. Muratovska A, Eccles MR. Conjugate for efficient delivery of short interfering RNA (siRNA) into mammalian cells. FEBS Lett. 2004; 558:63-68. [PubMed: 14759517]

26. Lafon M. Rabies virus receptors. J Neurovirol. 2005; 11:82-87. [PubMed: 15804965]

27. Lentz TL, Burrage TG, Smith AL, Crick J, Tignor GH. Is the acetylcholine receptor a rabies virus receptor? Science. 1982; 215:182-184. [PubMed: 7053569]

28. Barichello JM, Ishida T, Kiwada H. Complexation of siRNA and pDNA with cationic liposomes: the important aspects in lipoplex preparation. Methods Mol Biol. 2010; 605:461-472. [PubMed: 20072901]

29. Leng Q, Scaria P, Lu P, Woodle MC, Mixson AJ. Systemic delivery of HK Raf-1 siRNA polyplexes inhibits MDA-MB-435 xenografts. Cancer Gene Ther. 2008; 15:485-495. [PubMed: 18483501]

30. Leng Q, Woodle MC, Lu PY, Mixson AJ. Advances in systemic siRNA Delivery. Drugs Future. 2009; 34:721. [PubMed: 20161621] 
31. Morrissey DV, Lockridge JA, Shaw L, Blanchard K, Jensen K, Breen W, Hartsough K, Machemer L, Radka S, Jadhav V, Vaish N, Zinnen S, Vargeese C, Bowman K, Shaffer CS, Jeffs LB, Judge A, MacLachlan I, Polisky B. Potent and persistent in vivo anti-HBV activity of chemically modified siRNAs. Nat Biotechnol. 2005; 23:1002-1007. [PubMed: 16041363]

32. Rothdiener M, Muller D, Castro PG, Scholz A, Schwemmlein M, Fey G, Heidenreich O, Kontermann RE. Targeted delivery of siRNA to CD33-positive tumor cells with liposomal carrier systems. J Control Release. 2010; 144:251-258. [PubMed: 20184933]

33. Zimmermann TS, Lee AC, Akinc A, Bramlage B, Bumcrot D, Fedoruk MN, Harborth J, Heyes JA, Jeffs LB, John M, Judge AD, Lam K, McClintock K, Nechev LV, Palmer LR, Racie T, Rohl I, Seiffert S, Shanmugam S, Sood V, Soutschek J, Toudjarska I, Wheat AJ, Yaworski E, Zedalis W, Koteliansky V, Manoharan M, Vornlocher HP, MacLachlan I. RNAi-mediated gene silencing in non-human primates. Nature. 2006; 441:111-114. [PubMed: 16565705]

34. Allen TM, Hansen C, Martin F, Redemann C, Yau-Young A. Liposomes containing synthetic lipid derivatives of poly(ethylene glycol) show prolonged circulation half-lives in vivo. Biochim Biophys Acta. 1991; 1066:29-36. [PubMed: 2065067]

35. Harrington KJ, Rowlinson-Busza G, Syrigos KN, Uster PS, Abra RM, Stewart JS. Biodistribution and pharmacokinetics of 111In-DTPA-labelled pegylated liposomes in a human tumour xenograft model: implications for novel targeting strategies. Br J Cancer. 2000; 83:232-238. [PubMed: 10901376]

36. Baru M, Carmel-Goren L, Barenholz Y, Dayan I, Ostropolets S, Slepoy I, Gvirtzer N, Fukson V, Spira J. Factor VIII efficient and specific non-covalent binding to PEGylated liposomes enables prolongation of its circulation time and haemostatic efficacy. Thromb Haemost. 2005; 93:10611068. [PubMed: 15968389]

37. Papahadjopoulos D, Allen TM, Gabizon A, Mayhew E, Matthay K, Huang SK, Lee KD, Woodle MC, Lasic DD, Redemann C, et al. Sterically stabilized liposomes: improvements in pharmacokinetics and antitumor therapeutic efficacy. Proc Natl Acad Sci USA. 1991; 88:11460 11464. [PubMed: 1763060]

38. Harrington KJ, Rowlinson-Busza G, Uster PS, Stewart JS. Pegylated liposome-encapsulated doxorubicin and cisplatin in the treatment of head and neck xenograft tumours. Cancer Chemother Pharmacol. 2000; 46:10-18. [PubMed: 10912572]

39. Harrington KJ, Rowlinson-Busza G, Syrigos KN, Vile RG, Uster PS, Peters AM, Stewart JS. Pegylated liposome-encapsulated doxorubicin and cisplatin enhance the effect of radiotherapy in a tumor xenograft model. Clin Cancer Res. 2000; 6:4939-4949. [PubMed: 11156255]

40. Harrington KJ, Lewanski CR, Stewart JS. Liposomes as vehicles for targeted therapy of cancer. Part 2: clinical development. Clin Oncol (R Coll Radiol). 2000; 12:16-24. [PubMed: 10749015]

41. Goebel FD, Goldstein D, Goos M, Jablonowski H, Stewart JS. Efficacy and safety of Stealth liposomal doxorubicin in AIDS-related Kaposi's sarcoma. The International SL-DOX Study Group. Br J Cancer. 1996; 73:989-994. [PubMed: 8611437]

42. Northfelt DW, Dezube BJ, Thommes JA, Miller BJ, Fischl MA, Friedman-Kien A, Kaplan LD, Du Mond C, Mamelok RD, Henry DH. Pegylated-liposomal doxorubicin versus doxorubicin, bleomycin, and vincristine in the treatment of AIDS-related Kaposi's sarcoma: results of a randomized phase III clinical trial. J Clin Oncol. 1998; 16:2445-2451. [PubMed: 9667262]

43. Zamboni WC, Ramalingam S, Friedland DM, Edwards RP, Stoller RG, Strychor S, Maruca L, Zamboni BA, Belani CP, Ramanathan RK. Phase I and pharmacokinetic study of pegylated liposomal CKD-602 in patients with advanced malignancies. Clin Cancer Res. 2009; 15:14661472. [PubMed: 19190127]

44. Muggia FM, Hainsworth JD, Jeffers S, Miller P, Groshen S, Tan M, Roman L, Uziely B, Muderspach L, Garcia A, Burnett A, Greco FA, Morrow CP, Paradiso LJ, Liang LJ. Phase II study of liposomal doxorubicin in refractory ovarian cancer: antitumor activity and toxicity modification by liposomal encapsulation. J Clin Oncol. 1997; 15:987-993. [PubMed: 9060537]

45. Ranson MR, Carmichael J, O’Byrne K, Stewart S, Smith D, Howell A. Treatment of advanced breast cancer with sterically stabilized liposomal doxorubicin: results of a multi-center phase II trial. J Clin Oncol. 1997; 15:3185-3191. [PubMed: 9336354] 
46. Chekhonin VP, Zhirkov YA, Gurina OI, Ryabukhin IA, Lebedev SV, Kashparov IA, Dmitriyeva TB. PEGylated immunoliposomes directed against brain astrocytes. Drug Deliv. 2005; 12:1-6. [PubMed: 15801714]

47. Matveeva O, Nechipurenko Y, Rossi L, Moore B, Saetrom P, Ogurtsov AY, Atkins JF, Shabalina SA. Comparison of approaches for rational siRNA design leading to a new efficient and transparent method. Nucleic Acids Res. 2007; 35:e63. [PubMed: 17426130] 

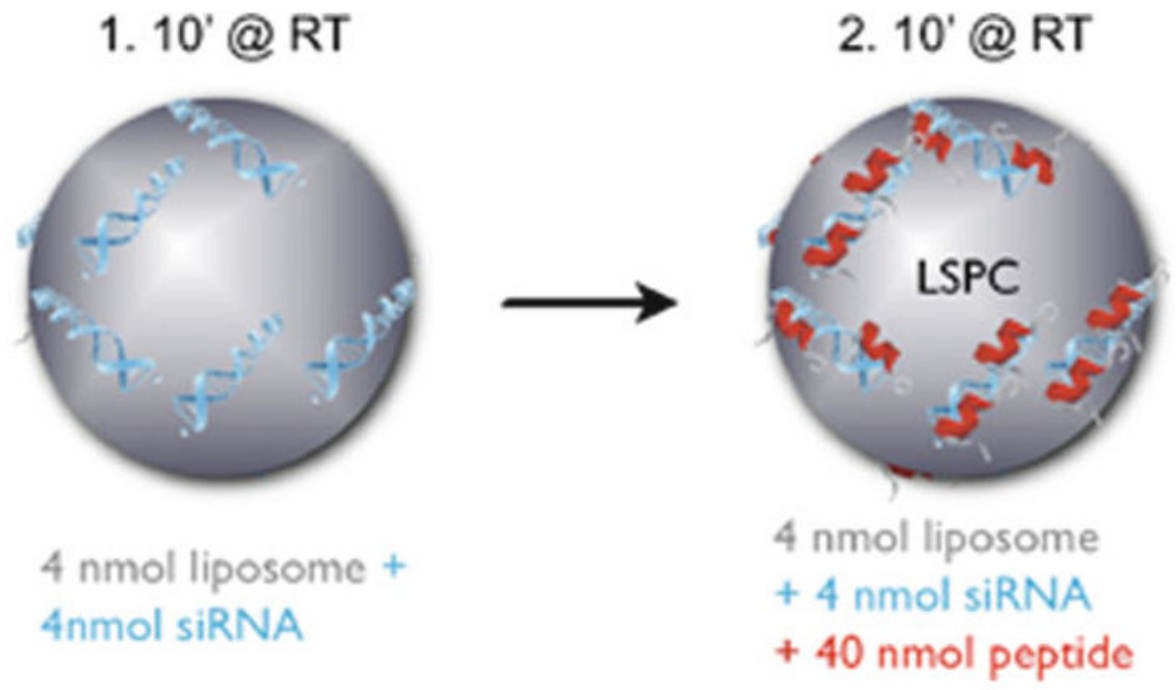

Fig. 1.

LSPC formulation. 

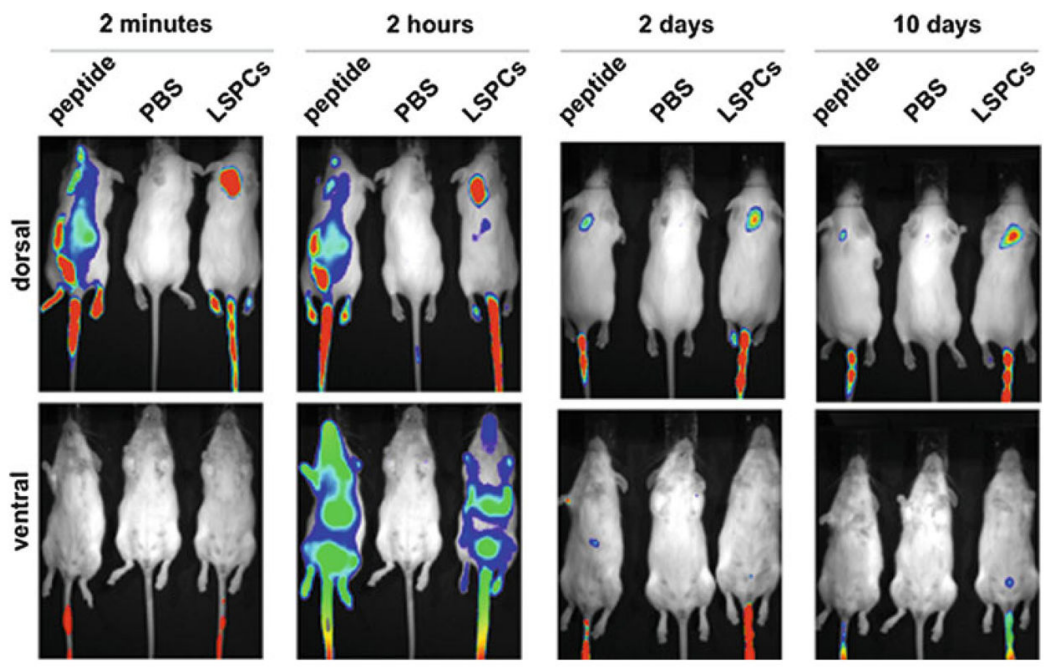

Fig. 2.

LSPC delivery to the CNS in live animals. Mice were injected iv into the tail vein with PBS alone (middle mouse in each panel), PrP siRNA complexed to the RVG-9r peptide (first mouse in each panel), or PrP LSPCs (third mouse in each panel). siRNA was detected in the brains of mice in as little as 2 min after injection. LSPCs targeted siRNA more specifically to the brain, where after at least 10 days post injection, we detected more LSPCs than siRNA complexed with peptide alone. 


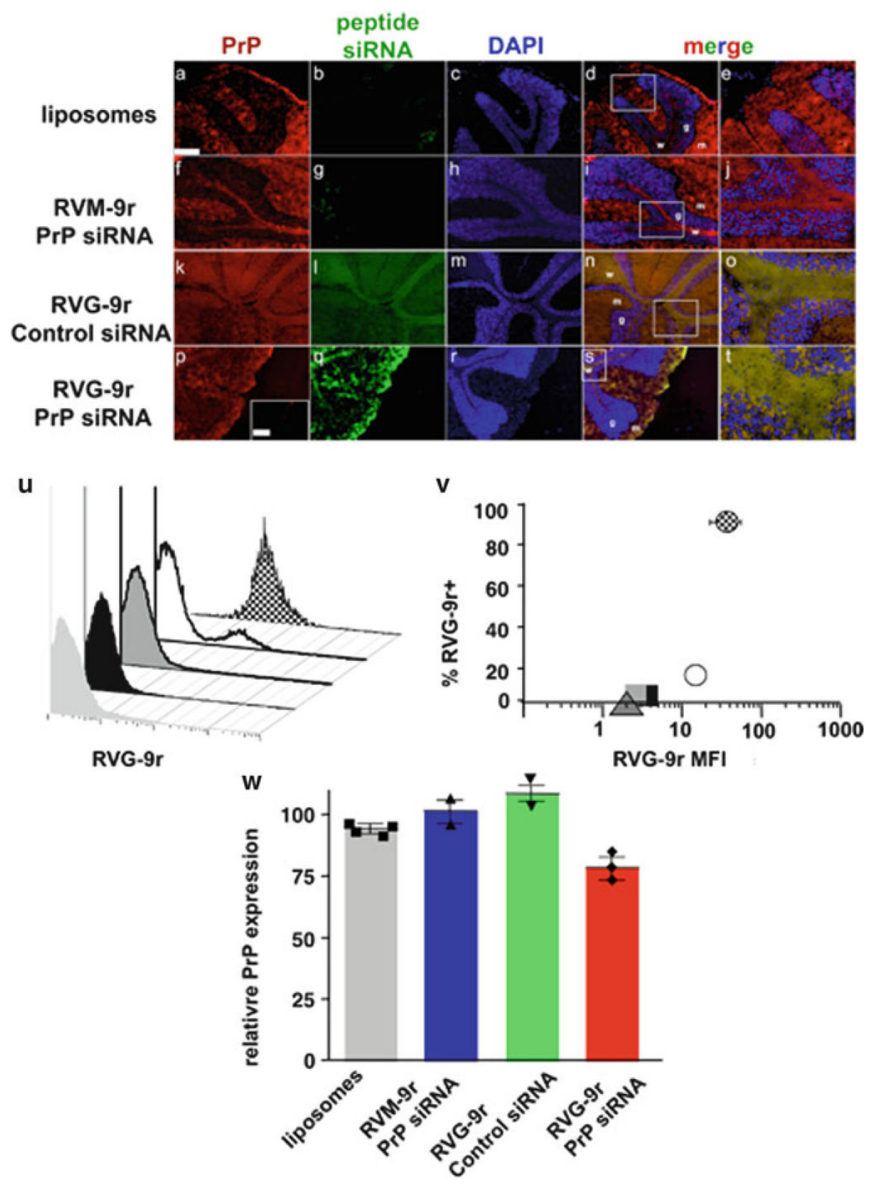

Fig. 3.

LSPC delivery to $\mathrm{PrP}^{\mathrm{C}}$-expressing cells in vivo (11). FVB mice were intravenously injected with liposomes alone (panels a-e) or LSPCs containing DyLight 488-labeled peptides and Alexa 488-labeled siRNAs as follows: PrP siRNA-control RVM-9r (f-j), Control siRNARVG-9r (k-o), or PrP siRNA-RVG-9r (p-t). Mice were sacrificed $24 \mathrm{~h}$ later, dissected, and their brains snap frozen and $8 \mu \mathrm{m}$ sections thereof stained with DyLight 649-labeled anti-PrP antibody (a, f, k, and $\mathbf{p}$ ) and DAPI (c, h, m, and $\mathbf{r})$ and visualized by fl uorescence microscopy. Panels (e), (j), (o), and (t) depict magnifications of the boxed areas in panels (d), (i), (n), and (s). Inset in panel (p) depicts a serial section stained with an irrelevant isotype control antibody. Scale bars, $50 \mu \mathrm{m}$. (u and v) FACS analysis of PrP-RVG-9r LSPC delivery to brain cells (checkered peak (u) and circle (v)), kidney cells (white peak and circle), splenocytes (dark grey peak and triangle), and hepatocytes (black peak and square). (w) Cumulative data showing relative PrP expression on brain cells treated with liposomes alone or with LSPCs containing PrP-RVM-9r, control-RVG-9r, or PrP-RVG-9r. Symbols associated with each bar indicate values for individual mice. 


\section{Table 1}

Delivery peptide sequences

RVG-9r $^{a} \quad$ YTIWMPENPRPGTPCDIFTNSRGKRASNGGGGrrrrrrrrr

RVM-9r $b \quad$ MNLLRKIVKNRRDEDTQKSSPASAPLDGGGGrrrrrrrrr

Lower case $r$ denotes D-arginine racemer

${ }^{b}$ Control 